\title{
WILD PLANTS USED AS VEGETABLE IN RUPANDEHI DISTRICT OF NEPAL AND THEIR ETHNOMEDICINAL IMPORTANCE
}

\author{
A.G. Singh ${ }^{1}$, M.P. Panthi ${ }^{1}$ and D.D. Tewari ${ }^{2}$
}

\section{ABSTRACT}

Consumption of green plant is a major source of vitamins and micronutrients for people using only vegetarian diets rich in carbohydrates. In rural areas where vegetable cultivation is not practiced and market supplies are not organized, local inhabitants depend on cultivated or wild indigenous vegetables for enriching the diversity of food. Knowledge of such food is part of traditional knowledge is largely transmitted through participation of individuals of households. The purpose of this study was to documentation of wild plants used as vegetables by the people of Rupandehi district, western Nepal. This paper revealed total 43 plant species belong to 36 genera under 29 families of vascular plants.

Key words: wild plants, Rupandehi, Terai, vegetables, consumption.

\section{INTRODUCTION}

Nepal is situated in the central Himalayas and occupies a total area of $147,181 \mathrm{~km}^{2}$ with rich biodiversity. The biodiversity is associated with the country's exceptional topographic, climatic, and agro-ecological conditions. About 1500 species of plants found in Nepal are considered useful (Manandhar 2002). Out of these, 651 species are economically useful including 440 species of wild food plants. About 200 plant species are consumed as vegetables (Manandhar 2002). Most of them however, are regarded underutilized or neglected.

Plants form an integral part of any society, any time. Use of plants as food, clothes, fodder, medicine, timber, etc. by man is since time immemorial. In remote rural societies where vegetable cultivation is not practiced and market is not available for local inhabitants, they should be dependent on locally available plants those can used as vegetables. Ethnic people from various tribes have been started using wild edible useful plants these days. That was the base of modern agricultural practices and related research. (Prescott and Prescott 1990, Scherrer et al. 2005, Bussmann et al. 2006). Consumption of green vegetables is a chief source of vitamins and micronutrients for those who are vegetarian. Knowledge of these edible plants is part of their traditional knowledge which is usually transmitted by elders to young ones and also by participation of individuals in collection of vegetable plants. Use of plants for one or other purpose is done by the human societies since very long period. While, the hunter gathers societies still continue to prefer such life styles, the agricultural societies did not eliminate the use of non-cultivated resources. Now a days, human vegetable consumption is based on rather very limited number of crops, but in many parts of the world the use of wild plants is very common (Bussmann and Sharon 2006, Kunwar et al. 2006, Cavender 2006, Pieroni et al. 2007).

Cultivating and gathering indigenous vegetables for both self consumption and sale are still very common in Nepal, particularly in remote areas. During food scarcity periods, people 
from urban and rural communities heavily depend on gathering these vegetables from their natural habitats (Manandhar 1982). Vegetables are the edible plants; they are obtained from both, underground as well as above the ground. They impart variety of flavor and test to the diet, making more appetizing and relishing. Now a day's, vegetables constitute an important part of the daily diet of millions of people all over the globe than ever before (Pandey 2008). The history of documentation on the utilization of the plant resources in Nepal dates back to the work of Banerji (1955). In this study, Banerji documented the various food and medicinal plants of eastern Nepal. After his work, some workers continued the ethnobotanical study in the 60's and 70's (Dobremez 1976, Pandey 1964). The reports on uses of plants by different Nepalese ethnic groups have been recorded only onwards 80's (Coburn 1984, Bhattarai 1989, 1990, 1991, 1992, 1993, Joshi and Edington 1990, Manandhar 1982, 1989, 1993, 2002, Mueller-Boeker 1993, Pohle 1990, Shrestha 1985, Shrestha and Pradhan 1986, Panthi and Chaudhary 2003, Bhattarai et al. 2009, Singh et al. 2011). These reports documented the information of uses of plant resources.

The main purpose of the study is to focus on wild vegetables and their ethnomedicinal importance to cure different ailments of human beings. Further, this study is significant for those who are mainly concern to such type of the study conduction. Through this study, many ethnic groups' who have been using such edible plants, their habit, and culture may be analyzed.

\section{STUDY AREA}

Rupandehi district is situated in the Western Development Region of Nepal between $27^{\circ} 20^{\prime} 00^{\prime \prime}$ to $27^{\circ} 47^{\prime} 25^{\prime \prime} \mathrm{N}$ latitude and $83^{\circ} 12^{\prime} 16^{\prime \prime}$ to $83^{\circ} 38^{\prime} 7^{\prime \prime}$ E longitude with an area of $1360 \mathrm{~km}^{2}$ (CBS, 2002). The average temperature ranges in between $8.75^{\circ} \mathrm{C}$ to $42.4^{\circ} \mathrm{C}$ and average annual rain fall is $1391 \mathrm{~mm}$. It is surrounded by Nawalparasi district from east, Kapilvastu district from west, hilly districts of Palpa and Arghakhanchi from north and Mahrajganj district of Uttar Pradesh (India) from south. The east, west and north sides of the district have high potentiality of plants of ethnobotanical importance like plants used as vegetable and cure of different disease. Hospital and healthcare facilities are poor in north and west sides of the district so inhabitants of this part basically rely on local plants and their products used in the treatment of common diseases by common traditional method.

The total population of this district is 708419 (District Profile Of Rupandehi 2007) Brahmin, Magar, Tharu, Muslim, Yadav, Chettry, Kewat,Chamar, Gurung,Newar, Kami, Teli, Kurmi, Koiri, Damai, Sonar, Thakuri are the major communities living in the district In above mentioned casts Tharu , Magar and Gurung communities have traditional knowledge of medicine and their mode of preparation and uses. Author visited villages and cities of Rupandehi district situated near the foot hills of Churia like Butwal Municipality, Gajedi, Rudrapur, Dudhraksh, Saljhandi, Parroha, Semlar, Motipur, and Devdaha Village Development Committees. The study areas are inhabited by Brahmin, Thakuri, Chhettry, and ethnic communities like Magar, Gurung, and Tharu.

Rupandehi district is characterized by tropical Sal (Shorea robusta) forest with tree associates like Sissoo (Dalbergia sissoo), Khayar (Acacia catechu), Saj (Terminalia alata), Banjhi (Anogeissus latifolia), Khaniyu (Ficus semicordata) etc. 


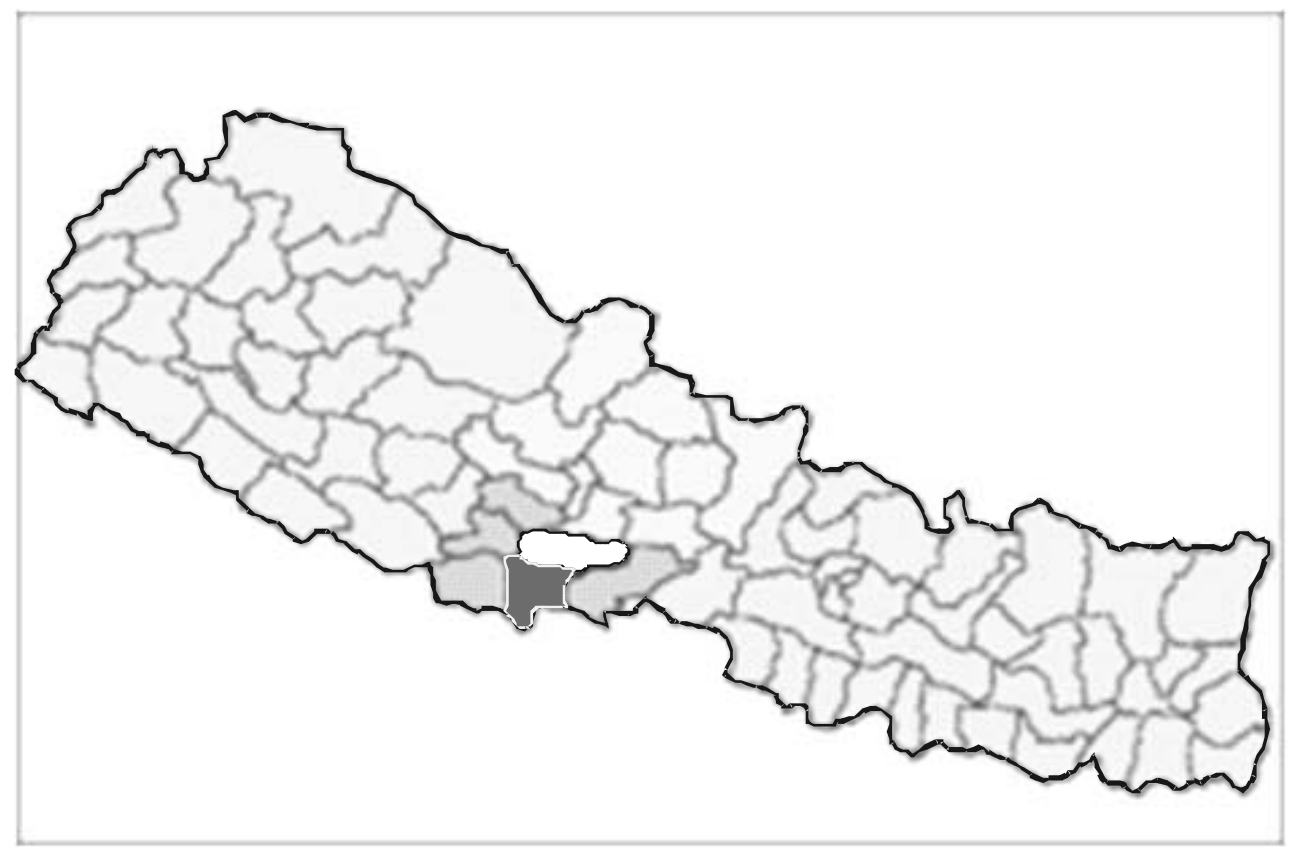

Fig. 1. Location of Rupandehi in map of Nepal, highlighted by blue colour (D D C, Rupandehi).

\section{MATERIALS AND METHODS}

The present study was undertaken in and around the main city and villages situated near the chure hills of Rupandehi district in the month of June to April 2010-11. During data collection professional people, villagers, wild plant collectors, were interviewing by preparing a semi structured questionnaire. The local names and traditional uses of plants were determined by the professional people. The information obtained was cross checked with the users. The voucher specimens were identified with the help of relevant taxonomic literature viz Polunin and Stainton (1984), Stainton (1988), Hara et al. (1978, 1979, 1982), Sharma (1999) and herbarium specimens of Butwal Multiple Campus Tribhuvan University, Butwal, Nepal.

\section{RESULTS AND DISCUSSION}

\section{Enumeration}

The results of the study are presented below in the form of alphabetical arrangement of plants scientific name followed by family, local name, voucher number, taxonomical character, and mode of uses. Altogether 43 plant species under 36 genera belongs to 29 Families of vascular plants were recorded.

Enumeration of plants with vegetable value in Rupandehi district, Nepal along with botanical characters and mode of uses (T: Tharu; $\mathrm{N}$ : Nepali) 
1. Amorphophallus campanulatus (Decne) Sivad. Araceae, Ole/ Suran/Kaan (N/T), AGS-72 Characters: Perennial tuberous herb, tubers depressed globose much warted dark brown, leaves large up to $3 \mathrm{~m}$, cauline, alternate.

Mode of Uses: Corms boiled add table salt, mustard oil and used as vegetable Ethnomedicinally use of boiled corms act as anti-inflammatory, digestive, appetizer. Oral uses of uncooked corm cure dysentery, piles, and hydrocele (Baral and Kurmi 2006).

2. Amaranthus lividus L., Amaranthaceae, Latte sag (N)/ Ban chaulai (T), AGS-27

Characters: Annual, erect ascending or prostrate, branched, glabrous, herb up-to $25 \mathrm{~cm}$ long. Leaves petioled, simple, oblong ovate or rounded, base acute and bilobed at the apex. Flowers in clusters densely aggregated into spikes.

Mode of Uses: Tender shoot boiled, fried or steamed and add pinch of salt and used as vegetable. Ethnomedicinally boiled vegetables are useful in liver disorders and anaemia (Bhattarai et al. 2009).

\section{Amaranthus spinosus L., Amaranthaceae, Kande lundo (N), AGS-15}

Characters: Annual, ascending or erect branched herb up-to $50 \mathrm{~cm}$ long with spiny shoot, Mode of Uses: Tender shoot eaten as vegetable after frying. Ethnomedicinally boiled tender shoot is useful in liver disorder. Root juice is used to treat fever, urinary disorders, diarrhea, and dysentery (Manandhar 1993).

\section{Amaranthus tricolor L., Amaranthaceae, Raato latte (N)/Chaulai (T), AGS-57}

Characters: Annual, erect or ascending branched, small sized reddish black herb up-to $25 \mathrm{~cm}$ long. Leaves simple, petioled, rhomboid-ovate, or lanceolate. Flowers small, green, clustered in axillary and terminal spikes.

Mode of Uses: Tender shoot is consumed as vegetable after boiling and frying. Leaf paste is applied on abscesses and septic ulcers. Leaf and seed decoction is used to check bleeding in prolonged menstruation, diarrhea and dysentery.

5. Anethum sowa Kura, Umbelliferae, Soya (T)/ Sounf sag (N), AGS-58

Characters: Pubescent annual, herb, leaves bi-tri pinnate compound, leaflets lanceolate or ovate, flowers white or light yellow in compound umbel inflorescence.

Mode of Uses: Boiled tender shoot is used as green vegetable. Fruits are digestive and stomachic useful in cough, asthma, and bronchitis. Seeds are used as spice.

\section{Asparagus racemosus Willd. Liliaceae, Kurilo (N)/ Santawar (T), AGS- 28}

Characters: Herbaceous, perennial, dioecious plant up-to $3 \mathrm{~m}$ tall. Root stocks fibrous, matted, some are fleshy. Young shoots cylindrical, fleshy, and juicy with numerous scales like leaves at the apex giving conical appearance.

Mode of Uses: It is consumed as one of the most delicious vegetables. The succulent shoots of Kurilo are used after cooking or eaten raw and also as soup. Kurilo contains alkaloid asparagines, which is diuretic and used in cardiac dropsy and chronic gout. Tuber used to 
treat amenorrhea, diarrhea and dysentery (Joshi 2008).

7. Basella alba L., Basellaceae, Poi sag (N)/ Pichko/ Poro (T), AGS-124

Characters: Climber or twiner, annual, herb, Leaves simple, alternate, petiolate, ovate, acute cordate at the base entire smooth, pinkish white flowers on axillary spikes.

Mode of Uses: Tender part is used as vegetable. Ethnomedicinally tender shoots are cooling, appetizer, tonic and diuretic.

8. Bassia longifolia Koenig, Sapotaceae, Mahuwaa (N/T), AGS-90

Characters: Perennial large sized tree, Leaves are linear lanceolate, acute, much tapered towards the base, flowers appearing with young leaves.

Mode of Uses: Flowers of the plant eaten raw or fried and used along with table salt. Ethnomedicinally flower cure cough, cold, and bronchitis.

9. Bauhinia variegata L., Leguminosae, Koiralo (N)/Kachnar/Koilara (T), AGS- 68

Characters: Medium sized (up to $6 \mathrm{~m}$ tall), deciduous tree, leaves broad, alternate, cordate and petiolate, flowers pink or purple on corymbose inflorescence.

Mode of Uses: Young tender shoot and unripe fruit is used as vegetable. Floral bud is boiled, sprinkle salt and used as pickles. Ethnomedicinally decoction of dried flower buds and flowers is given in diarrhoea, dysentery, and piles (IUCN 2004). Flowers are astringent and used cure leucorrhea, diarrhea and hemorrhage (Bajracharya 1979). Flower juice is taken for diarrhoea and dysentery (Manandhar 2002).

10. Boerhaavia diffusa L., Nyctaginaceae, Punarnavaa (N), AGS-91

Characters: Profusely branched, perennial, herb, leaves thick ovate, oblong. Purpled coloured small flowers in axillary and terminal panicles.

Mode of Uses: Tender shoot is cooked and used as vegetable. Ethnomedicinally leaves are useful in inflammation of eyes and gonorrhea. Leaf paste is taken orally to check bleeding after delivery. Leaves are used in hepatopathy.

11. Capsella bursa-pastoris (L.) Medikus, Cruciferae, Chamsure Jhar (N), AGS-74

Characters: Annual, erect herb up to $15-40 \mathrm{~cm}$ high, leaves radical, oblong or lanceolate, pinnately compound, flowers white in colour on corymbose inflorescence.

Mode of Uses: Tender shoot is used as vegetable. Ethnomedicinally juice of plant is useful in control of bleeding from cut or wounds.

12. Chenopodium album L., Chenopodiaceae, Bethe (N)/ Bethuwa (T), AGS-09

Characters: Annual, erect, herb up to $20-80 \mathrm{~cm}$ high, ovate or oblong, alternate, leaves on petiole, flowers purple and clustered in axillary spikes.

Mode of Uses: Boiled tender shoot used as vegetable. Ethnomedicinally it has anthelmintic property Joshi and Joshi 2000), and used as tonic.

13. Chenopodium murale L., Chenopodiaceae, Kalo bethe/ Chirua bethe (N), AGS-131 
Characters: Annual, erect, herb, upto one meter high, alternate, irregularly serrated, incised, petioled, simple, leaves.

Mode of Uses: Seed powder boiled in milk and use to cure fever. Fresh juice of plant taken along with common salt cure gastritis.

14. Coccinia grandis (L.) Voigt, Cucurbitaceae, Golkakari (N), Kundaru (T), AGS-109

Characters: Annual, prostrate herbs, petiolate, palmately lobed leaves, elongated slender tendril, white flowers in solitary form.

Mode of Uses: Fruits are used as vegetable. Ethnomedicinally fruit is eaten raw to cures toothache. Leaf juice is used against liver disease.

15. Commelina paludosa BI., Commelinaceae, Kane sag (N), AGS-85

Characters: Perennial, scrambling herb, stem branched from the base creeping and rooting below, Leaves sub sessile, lanceolate-oblong, acuminate or acute, slightly oblique at base.

Mode of Uses: Tender shoot is used as vegetable. Ethnomedicinally it is useful in digestive disorders (Joshi 2008).

16. Colocasia esculenta (L.) Schott. Araceae, Karkalo/Gabha (N) / Ghuiya/ Arvi (T), AGS-19

Characters: 1-2 $\mathrm{m}$ tall herbaceous plant with a short underground corm (30 cm long and 15 $\mathrm{cm}$ in diameter) and spirally arranged long petioled spear shaped leaves with prominent veins. Underground corms are rough, marked by number of rings representing nodes of the stem. Each main corm gives rise to small side cormels, variable in number and size.

Mode of Uses: The corms are used as vegetable in various ways- roasted, boiled, and baked. Young leaves and petioles are widely used as vegetable. Young leaves along with beshan (flour of gram seed) and common salt and spices are used to prepare pakouda. Leaf juice is useful in earache and bleeding from ear (Baral and Kurmi 2006). Corms are used to manufacture alcohol.

\section{Crateva unilocularis Buch-Ham., Capparaceae, Sipligan (N), AGS-88}

Characters: Small sized branched perennial tree, leaves are simple, petiolate, lanceolate, entire, acute, and cordate.

Mode of Uses: Young leaves are boiled and used as vegetable and also prepare pickles. Decoction of bark $20 \mathrm{ml}$ twice a day for 15 days is useful in expelling kidney stone (Panthi et al. 2003).

\section{Cucurbita maxima Duchesne, Cucurbitaceae, Pharsi (N)/ Kohara (T), AGS-102}

Characters: Herbaceous, climber leaves nearly spherical in outline with deep notches at base Mode of Uses: Tender shoot is used as green vegetable and fruits eaten raw or after boiling used as vegetable. Ethnomedicinally fruits have cooling effect useful in the internal inflammation.

19. Dendrocalamus hamiltonii Nees \& Arn ex Munro, Gramineae, Tama bans (N), AGS-67

Characters: Thick walled perennial tall and erect bamboo about $20 \mathrm{~m}$ height, nodes swollen with whitish ring above hairy below, internodes long, leaves lanceolate stalked alternate at the base 
Mode of Uses: Young growing stem is used as vegetable in the form of tama. Ethnomedicinally oral use of tama has cooling effect prevents inflammation in stomach (Coburn 1984).

20. Dioscorea bulbifera L., Dioscoreaceae, Gatthe tarul (N/T), AGS-82

Characters: It is deep rooted, climbing, dioecious perennial vine. Leaves petiolate, simple, opposite or alternate and cordate or deeply lobed, Stem 3-12 m long with climbing roots

Mode of Uses: Tubers are consumed after boiling, frying steaming or roasting. Ethnomedicinally it is useful in diarrhea, dysentery and piles (Joshi et al. 2011).

21. Dioscorea deltoidea Wall., Dioscoreaceae, Bhyakur/Yam (N)/ Tarul (T), AGS-75

Characters: It is deep rooted, climbing, dioecious perennial vine, leaves petiolate, simple, opposite or alternate and cordate. Stem 4-7 m long with climbing roots

Mode of Uses: Tubers are eaten after boiling, frying, roasting, or steaming. Ethnomedicinally It acts as anti-inflammatory. It is also useful in diarrhoea and dysentery (Poudyal 2001). Axillary bulbs are boiled and taken for gastric troubles and bloody dysentery (Joshi 2008).

22. Dioscorea pentaphylla L., Dioscoreaceae, Ban tarul (N/T), AGS-32

Characters: Climbing perennial vine. Leaves petiolate, simple, 3-5 foliate, leaflets ellipticlanceolate, ovate or obovate, alternate or opposite, tubers oblong, flowers in spikes.

Mode of Uses: Tubers are eaten after boiling, frying steaming, or roasting. Ethnomedicinally tuber cures bleeding piles \& tuberculosis (Coburn 1984).

23. Dryoanthyrium boryanum (Willd.) Ching, Aspidiaceae, Kalo niuro (N), AGS-113

Characters: Rhizomatous, perennial, herbs, aerial parts, and underground part are covered with hairs, Leaves pinnately compound, petiolate and bear spores on underside Young leaf of the plant shows a characteristic circinate venation.

Mode of Uses: Young aerial part of the plant is used as vegetable and pickles in various ways- roasted, boiled, or steamed. Ethnomedicinally young shoot are cooked and taken for stomach problem (Gurung et al. 2008).

24. Fagopyrum esculentum Moench, Polygonaceae, Phapaer (N), AGS-77

Characters: Annual, herb leaves alternate, petiolate, cordate or triangular, acute, entire, and smooth. Flowers are pinkish white and arranged in axillary and terminal cyme.

Mode of Uses: Tender shoot used as vegetable. Ethnobotanically flour prepared from the seed is used as holy item in manufacture of chapatti during fasting periods (Brat) of Hindu religion.

25. Ficus lacor Buch-Ham., Moraceae, Kaabhro (N), AGS-111

Characters: Small sized perennial tree, membranous ovate-oblong leaves on long petioles with entire margin.

Mode of Uses: Newly born leaves are boiled, cooked and sprinkle table salt and used as vegetable and pickles. Ethnomedicinally decoctions of leaves are act as blood purifier, latex of the plants used in cut, wounds, and pimples. 
26. Ficus rumphii Bl., Moraceae, Pakar (N/T), AGS-83

Characters: Large sized (up to 5-7 m tall) deciduous tree, ovate, entire, smooth leaves are petiolate on alternate manner.

Mode of Uses: Newly born leaves are used as pickles and delicious vegetable after boiling. Fruit juice applied externally to kill worms.

27. Ipomoea aquatica Forssk., Convolvulaceae Karmaiya Sag (T)/ Kerunga sag (N), AGS-16

Characters: Perennial, trailing vine permeating all the parts. Stem is thin, pubescent, with lanceolate, petiolate, entire, acute, leaves arranged alternately. Flowers are bell shaped violate small and are borne in an axillary cyme inflorescence.

Mode of Uses: Young and tender shoots are used as vegetable in various ways. Ethnomedicinally plant decoction is used in nervous and general debility.

28. Lepidium sativum L., Cruciferae, Chamsur (N/T), AGS- 63

Characters: Annual, erect herb up to $35 \mathrm{~cm}$ high, lower leaves radical, long, and decompounds, flowers small and white in long raceme. Frequently found in moist, shady places along road sides in waste lands and cultivated fields.

Mode of Uses: Tender shoot is used as vegetable. Ethnomedicinally tender shoot is used in case of liver complaints, syphilis, bleeding piles, asthma, and cough (Malla and Chhetry 2009). Seed boil in milk are given daily on an empty stomach for lactation to women after child birth and also used to cure backache.

29. Leucas cephalotes (Roth.) Spreng, Labiatae, Gumma (T)/ Dron pushpi (N), AGS-120

Characters: Erect annual, herb, leaves subsessile, lanceolate, more or less pubescent flowers bilabiate white and long.

Mode of Uses: Steamed tender shoot along with common salt is used as vegetable. Ethnomedicinally it is useful in digestive problems. Flower decoction is used to reduce sugar level in blood.

30. Manihot esculenta Crantz, Euphorbiaceae, Simal tarul (N), AGS-81

Characters: It is a shrubby, perennial plant up-to $3 \mathrm{~m}$ of height. Stem erect, smooth marked by prominent knobby leaf scars. Leaves palmately compound, spirally arranged; leaflets 3-7, ovate-lanceolate, dark green, small flowers born in axillary racemes.

Mode of Uses: Tubers are eaten fresh, after roasting or boiling Ethnomedicinally use of tubers cure bleeding piles.

31. Mentha spicata L., Labiatae, Pudina (N)/ Patina/ Bawari (T), AGS- 18

Characters: Aromatic perennial, herb with creeping rhizome, leaves simple, oblong, elliptic, acute, cordate, or round base wavy margins, glabrous or sparsely hairy and sub-sessile

Mode of Uses: Leaves and young stems are used as chatani (pickle). Ethnomedicinally decoction of tender shoots along with sugar cube or common salt is used as sarbat to save from sun stroke and give cooling effect; pickle is taken to improve appetite. 
32. Moringa oleifera Lam., Moringaceae. Shaijan (T)/ Shital-chini (N), AGS-93

Characters: A small or medium sized deciduous, tree, leaves tripinnate, leaflets 6-9 pairs, long, elliptic, ovate or obovate, flowers white in large panicles. Fruits are 9 ribbed $20-35 \mathrm{~cm}$ long pendulous capsules.

Mode of Uses: Unripe young fruits are used as delicious vegetable. Ethnomedicinally the fresh juice of root bark is used in earache. Flowers are also used as vegetable to make the body resistant against small pox.

33. Murraya koenigii (L.) Spreng, Rutaceae, Karipatta /Methonim (N), AGS-112

Characters: Small deciduous strongly scented pubescent shrub, leaves long imparipinnate, leaflets 10-25, ovate, or lanceolate, acuminate or retuse, crenulated, oblique at the base, flowers white fragrant and small.

Mode of Uses: Leaves are roasted and used in vegetable for good fragrance and taste. Ethnomedicinally the green leaves are eaten raw in case of diarrhea and dysentery (Dhami 2008, Acharya and Acharya 2009). Extract of roasted leaves is given to check vomiting. Leaf paste also destroys pathogenic organisms. Plants are used as insect repellent (Uprety et al. 2010).

34. Ophioglossum petiolatum Hook., Ophioglossaceae, Jibre sag (N), AGS-96

Characters: Herbaceous, erect with short perennial rhizome, Fronds 2-5 inches long and simple. Mode of Uses: Tender aerial part is used as vegetable. Paste of aerial parts applied to cut and wounds and also checks bleeding from nose.

35. Portulaca oleracea L., Portulacaceae, Nun dhiki (N)/ Amlonia (T), AGS- 78

Characters: Prostrate, succulent, branched herb, branch-lets are smooth, green or purple, Leaves alternate or sub-opposite, obovate, obtuse and fleshy smooth. Yellow coloured flowers clustered at the tips of branches.

Mode of Uses: Sour and salty tender shoot boiled, cooked and used as vegetable. Ethnomedicinally use of plant is stomachic, antibacterial, diuretic, and tonic. They are also useful in gastropathy, nephropathy, otalgia, dysentery, and jaundice. Leaves are used for scurvy, kidneys, and cardio-vascular disorders.

36. Rorippa nasturtium-aquaticum (L.) Hayek, Cruciferae, Sim rayo / Sim sag (N), AGS-99

Characters: Annual, erect herb, leaves radical oblong -lanceolate, flowers white in terminal racemes.

Mode of Uses: Tender shoot is used as vegetable. Ethnomedicinally it has digestive power and also used as tonic.

37. Rumex nepalensis Spreng, Polygonaceae, Halhale sag (N/T), AGS-61

Characters: Herbaceous, perennial, plants up to $50 \mathrm{~cm}$ high with spreading branches, leaves entire, sessile in upper part and petiolated in lower part flowers small arranged in a spike inflorescence.

Mode of Uses: Tender shoots are used as vegetable. Ethnomedicinally boiled tender shoot 
cure stomachache. Fresh leaf extract and sap is applied on cuts, wounds, and swellings.

38. Smilax macrophylla Roxb., Smilacaceae, Kukur dino (N), AGS-86

Characters: Climbing, shrub with sparsely prickled stem up to $2.5 \mathrm{~cm}$ diameter leaves petiolate ovate-oblong to elliptic arranged alternately on nodes of main stem and their branches. Flower small arranged in umbels (Panthi et al. 2003).

Mode of Uses: Tender shoot is used as vegetable in roasted or boiled form. Ethnomedicinally it is used in stomachache or gastritis. Root juice is better remedy against bloody stools and gonorrhea. Root extract cures scabies (Manandhar 2002) and purifies blood (Baral and Kurmi 2006)

39. Solanum nigrum L., Solanaceae, Kaligedi (N), Kamai (T), AGS-02

Characters: Annual, erect, glabrous herb upto $40 \mathrm{~cm}$ high. Leaves simple, petioled, ovate, or oblong. Flowers white in sub umbellate cyme.

Mode of Uses: Tender shoot is boiled, fried, and used as vegetable. Fruit is used to treat fever, diarrhea and dysentery. Fresh fruit juice is applied over forehead to treat headache (Bhattarai et al. 2009).

40. Spinacia oleracea L., Chenopodiaceae, Gobre palungo (N)/ Palak (T), AGS-84

Characters: It is a fast growing, biennial, herbaceous plant with stout plate like stem bearing simple, smooth, dark green, petiolate rosette of leaves

Mode of Uses: It is a very nutritious vegetable used as soup, cooked, fried or as salad. Ethnomedicinally It is diuretic and antibacterial. Fruits are used in fever and inflammatory bowels.

41. Urtica dioica L., Urticaceae, Sisnu (N), AGS-108

Characters: Annual herb, lanceolate or ovate leaves with pointed apex ant toothed margin. Entire plant is covered with small white colour hairs.

Mode of Uses: Tender shoot boiled and used as green vegetable. Ethnomedicinally plant decoction is diuretic and used in reduction of sugar label in blood. Use of tender shoot as vegetable relieve from rheumatic problems (Poudyal 2001).

42. Vicia angustifolia Vahl., Leguminosae, Kutali kosha (N), Ankara, Sanai pati (T), AGS- 114 Characters: Annual, erect, highly branched shrub, pinnately compound leaves, leaflets are oval-lanceolate. Flowers arranged on racemose fashion in axillary position.

Mode of Uses: Flowers cooked and used as vegetable. Ethnomedicinally infusion of leaves is useful in constipation, jaundice, anaemia and in liver problems. Paste of the leaves mixed in lemon juice and applied on affected parts of ringworm (Daad)

43. Zingiber officinale Rosc., Zingiberaceae, Soanth (T)/ Aduwa (N), AGS- 94

Characters: Erect rhizomatous herb, rhizome is yellow in colour without any definite shape, Leaves lanceolate, flowers pendulose green spike.

Mode of Uses: Rhizome is used as pickles and spice. Ethnomedicinally use of rhizome as 
pickles or spice is thermogenic. Dried rhizome powder and rock salt mixed to prepare churan is useful in dyspepsia (Devaraj 1998). Filtered juice of rhizome put inside the nose for sinusitis (Poudyal 2001, Bhattarai et al. 2009).

Abbreviations: $\mathrm{T}=$ Tharu, $\mathrm{N}=$ Nepali.

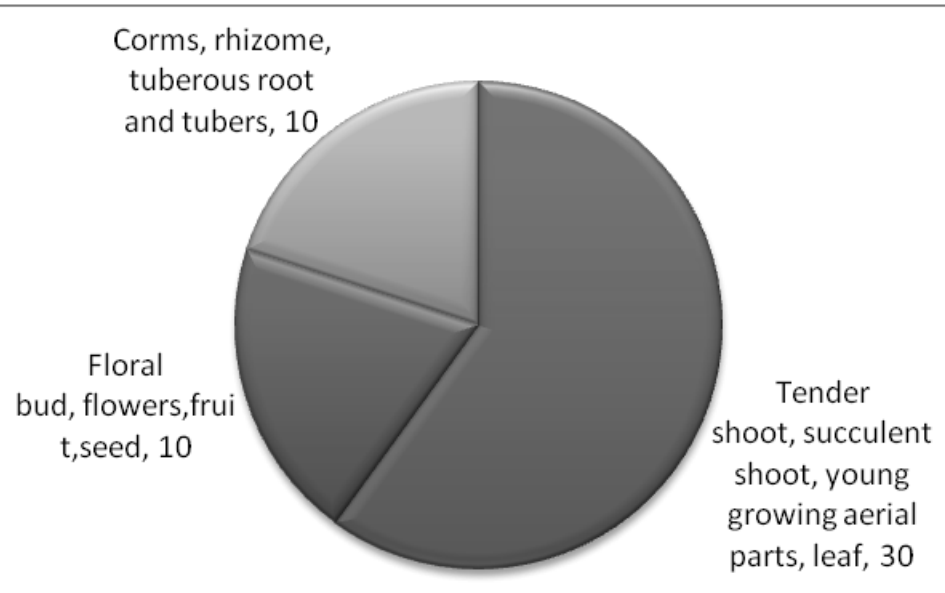

Fig. 2. Plant parts used as vegetable and in cure of diseases.

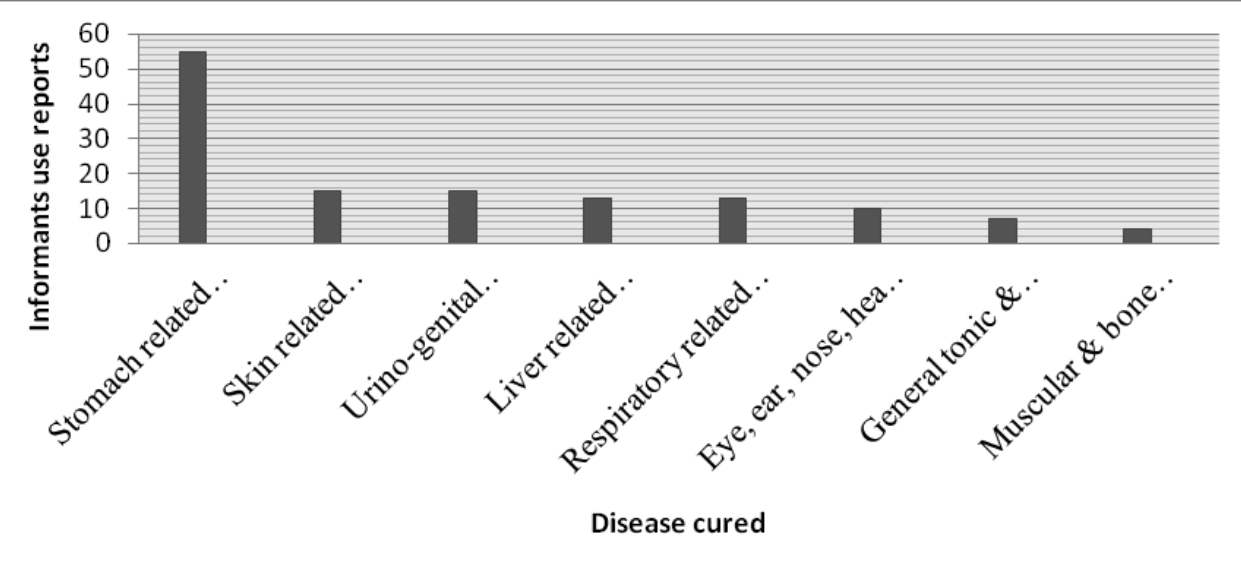

Fig 3. Name of the diseases cured.

This study contributes to the information on knowledge of wild plants used as vegetables by the people of Rupandehi district, Nepal. Focus group discuss resulted 43 plant species for their medicinal and dietary significance, all the species of wild vegetables were already studied for their medicinal properties and uses by the country people as well as outside world. These 
wild vegetables are used for various health ailments as shown in diagrams. The informations presented here might be helpful for further studies on wild plants for nutritional values and possible effects. Furthermore, more attention should be given on sustainable management and sustainable harvesting of useful plant parts of wild plants.

\section{ACKNOWLEDGEMENTS}

First of all authors thanks to the people who give us knowledge about mode of use of the cultivated/wild plants as vegetables and there ethnobotanical aspects, without their active participation this paper would not have been possible. We are also grateful to the campus chief Mr. S. P. Gewali, Professor Dr. D. N. Pathak (Chemistry), Mr. M. L. Chaudhary, (Mathematics) of Butwal Multiple Campus and our departmental colleagues for valuable encouragement to prepare the paper and special thanks to Mr. Kam Bahadur Gaha (Head Lab Boy of Botany Department, BMC) who helped us for collection of plant materials and preparation of herbarium.

\section{REFERENCES}

Acharya, R. and K.P. Acharya, 2009. Ethnobotanical study of medicinal plants used by Tharu community of Parroha VDC, Rupandehi district, Nepal. Scientific world, 9:81-85.

Bajracharya, M.B.,1979. Ayurvedic medicinal plants and general treatment. Piyusavarsi Ausadhalaya Mahaboudha, Kathmandu, Nepal, $230 \mathrm{p}$.

Banerji, M.L.,1955. Some edible and medicinal plants from east Nepal. Journal of Bombay Natural History Society, 35:153-155.

Baral, S.R. and P.P. Kurmi, 2006. A compendium of medicinal plants in Nepal. Published by Mrs. Rachana Sharma, Maijubahal, Chabahil Kathmandu, Nepal, 281 p.

Bhattarai, N.K.,1989. Traditional phytotherapy among the Sherpa's of Helambu, central Nepal. Journal of Ethnopharmacology, 27:45-54.

Bhattarai, N.K.,1990. Herbal folk medicines of Kabhrepalanchok district, central Nepal. International Journal of Crude Drug Research, 28(3):225-231.

Bhattarai, N.K.,1991. Folk herbal medicines of Makawanpur district, Nepal. International Journal of Pharmacognosy, 29(4):284-295.

Bhattarai, N.K.,1992. Medical ethnobotany in the Karnali zone, Nepal. Economic Botany, 46(3):257-261.

Bhattarai, N.K.,1993. Folk herbal medicines of Dolkha district, Nepal. Fitoterapia, LX IV (5):387-395.

Bhattarai, S., R.P. Chaudhary and R. S. L. Taylor, 2009. Ethnomedicinal plants used by the people of Nawalparasi district, central Nepal. Our Nature, 7:82-99.

Bussmann, R. W. and D. Sharon, 2006. Traditional medicinal plant use in northern Peru: Tracking two thousand years of healing culture. Journal of Ethnobiology and Ethnomedicine, 2:47.

Bussmann, R.W., G.G. Gilbrreath, J. Solio, M. Lutura, R. Latuluo, K. Kunguru, N. Wood and S. G. Mathenge, 2006. Plant use of the Maasai of Sekenani Valley, Maasai Mara, Kenya. Journal 
of Ethnobiology and Ethnomedicine, 2:22.

Cavender, A., 2006. Folk medicinal uses of plant foods in southern Appalchia United states. Journal of Ethnopharmacology, 108:74-84.

CBS, 2002. Population of Nepal: Village Development Committees/ Municipalities' population census 2001. Ramshah Path, Thapathali Kathmandu, Nepal.

Coburn, B.,1984. Some native medicinal plants of the western Gurung. Kailash, XI (1-2):55-88.

Devaraj, T.L.,1998. Ayurvedic remedies for common diseases. Sterling Publishers (P) Ltd., New Delhi, India.

Dhami, N., 2008. Ethnomedicinal uses of plants in western terai of Nepal: A case study of Dekhatbhuli VDC of Kanchanpur district. In Jha, P.K., S.B. Karmacharya, M.K. Chettry, C.B. Thapa, and B.B. Shrestha (eds) Medicinal plants in Nepal: An anthology of contemporary research. Ecological Society of Nepal (ECOS), Kathmandu, pp 165-177.

District Profile, 2007. District Development Committee, Rupandehi, Lumbini Zone, Nepal.

Dobremez, J.F.,1976. Exploitation and prospects of medicinal plants in eastern Nepal In Mountain Environment and Development. Swiss Association for Technical Assistance in Nepal, Kathmandu.

Gurung, L. J., S. Rajbhandary, and S. Ranjitkar, 2008. Indigenous knowledge on medicinal plants in mid hills of Nepal: A case study of Sikles area of Kaski district. Ecological Society of Nepal (ECOS), Kathmandu, pp 153-164.

Hara, H., and L.H.J. Williams,1979. An enumeration of the flowering plants of Nepal. Vol. 2, British Museum (Natural History), London, UK.

Hara, H., A.O. Chater and L.H.J. Williams,1982. An enumeration of the flowering plants of Nepal. Vol. 3, British Museum (Natural History), London, UK.

Hara, H., W.T. Stearn and L.H.J. Williams,1978. An enumeration of the flowering plants of Nepal. Vol. 1, British Museum (Natural History), London, UK.

IUCN, 2004. National register of medicinal and aromatic plants (revised and updated).

Joshi, A. R. and K. Joshi, 2000. Indigenous knowledge and uses of medicinal plants by Local communities of the Kali Gandaki watershed Area, Nepal. Journal of Ethnopharmacology, 73: $175-183$.

Joshi, A. R. and J. M. Edington,1990. The use of medicinal plants by two village communities in the Central Development Region on Nepal. Economic Botany, 44(1):71-83.

Joshi, K.R., 2008. Ethnomedicinal uses of plants- A case study of Sharmol VDC, Darchula District, Nepal: Medicinal plants in Nepal. An Anthology Contemporary Research, pp 177-186. Joshi, K., R. Joshi and A.R. Joshi, 2011. Indigenous knowledge and uses of medicinal plants in Machhegaun, Nepal. Indian Journal of Traditional Knowledge, 10: 281-286.

Kunwar, R.M., B. K. Nepal, H.B. Kshhetri, S.K. Rai and R.W. Bussmann, 2006. Ethnomedicine in Himalaya: A case study from Dolpa, Humla, Jumla, and Mustang districts of Nepal. Journal 
of Ethnobiology and Ethnomedicine, 2:27.

Malla, B. and R.B. Chhetri, 2009. Indigenous knowledge on ethnobotanical plants of Kavrepalanchowk district. Kathmandu University Journal of Science, Engineering, and Technology, 5: 96- 109.

Manandhar, N.P.,1982. Wild edible plants of Nepal. Bull. Dept. Med. PI., No. 11. Thapathali, Kathmandu, Nepal.

Manandhar, N.P.,1989. Useful wild plants of Nepal. Nepal Research Centre Publications No. 14. Steiner, Stuttgart, Germany.

Manandhar, N. P.,1993. Herbal remedies of Surkhet district, Nepal. Fitoterapia, 64 (3):265-272.

Manandhar, N.P., 2002. Plants and people of Nepal. Timber Press Portland Oregon, USA.

Mueller-Boeker, U.,1993. Ethnobotanical studies among the Chitwan Tharus. Journal of Nepal Research Centre, 9:17-56.

Pandey, B.D.,1964. The wealth of medicinal plants of Nepal. Peking Symposium, China, pp 183-140.

Pandey, H. P., 2008. Economic Botany. Silver Line Publications 17/3 Mathura Road, Faridabad U.P., India.

Panthi, M.P. and R.P. Chaudhary, 2003. Ethnomedicinal plant resources of Arghakhanchi District, West Nepal, Journal of Ethnobotany, 15:71-86.

Pieroni, A, L. Houlihan, N. Ansari, B. Husain and S. Astam, 2007. Medicinal perception of vegetable traditionally consumed by South-Asian migrants living in Bradford, northern England. Journal of Ethnopharmacology, 113:100-110.

Pohle, P.,1990. Useful plants of Manang district. Franz Steiner Verlag Wiesbaden GMBH, Stuttgart, Germany.

Polunin, O. and A. Stainton,1984. Flowers of the Himalayas. Oxford University Press, New Delhi, India.

Poudyal,K.N.,2001.Jadibuti Bigyan. Smt. Mina Poudel, Shankar Nagar-3 Rupandehi, Nepal.

Prescott-Allen, O.C. and R. Prescott-Allen,1990. How many plants feed the world? Conservation Biology, 4: 365-374.

Scherrer, A.M., R. Motti and C.S. Weckerle, 2005. Traditional plant use in the areas of Monte Vesole and Ascea,Cilento National Park (Campania, southern Italy). Journal of Ethnopharmacology, 97:129-143.

Sharma, O. P.,1999. Plant Taxonomy. Tata McGraw-Hill Publishing Company Limited, New Delhi, India.

Shrestha, I. and N. Pradhan,1986. Medicinal plants of Chobhar village of Kathmandu district, Nepal. Journal of Natural History Museum, 10(1-4):65-72. 
Shrestha, P.,1985. Contribution to the ethnobotany of the Palpa areas. Contribution to Nepalese Studies, 12(23):63-74.

Singh, A.G., K.N. Poudel and D.D.Tewari, 2011. Diversity of cultivated and wild medicinal plants used by the people of Devdaha VDC of Rupandehi district west Nepal. Current Botany, 2 (2):34-42.

Stainton, A.,1988. Flowers of the Himalaya. A supplement, Oxford University Press, New Delhi, India.

Uprety, Y., E.K. Boon R.C. Poudel, K.K. Shrestha, S. Rajbhandary, A. Ahenkan and N. N. Tiwari, 2010. Non-timber forest products in Bardiya district of Nepal: Indigenous use, trade, and conservation. Journal of Human Ecology, 30(3):143-158.

\section{AUTHOR'S ADDRESS}

\section{Anant Gopal Singh ${ }^{1}$ and M.P. Panthi ${ }^{1}$}

Department of Botany, Butwal Multiple Campus,

Tribhuvan University, Butwal, Nepal

(email: agsingh26@gmail.com)

D.D. Tewari ${ }^{2}$

Department of Botany,

M.L.K. (P.G.) College, Balrampur Dr. R.M.L. Awadh University, Faizabad, U.P. (India). 